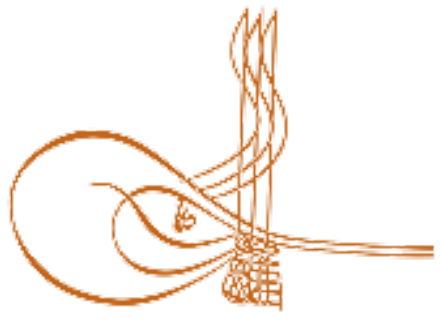

www.turkishstudies.net/education
Turkish Studies - Educational Sciences

eISSN: $2667-5609$

Research Article / Araștırma Makalesi

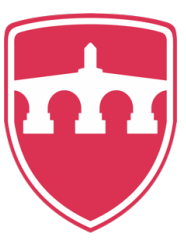

INTERNATIONAL

BALKAN

UNIVERSITY

Sponsored by IBU

\title{
İkinci Yabancı Dil Olarak Almanca Öğretiminde Öğretmenlerin Karşılaştıkları Sorunlar*
}

\author{
The Problems Encountered by Teachers in German Teaching as Second Foreign Language
}

\author{
Ayşe Ülkü Kan ${ }^{* *}$ - Neslihan Durak Koç***
}

\begin{abstract}
This study was carried out to determine the problems faced by teachers in teaching German as a second foreign language. In this research, which was conducted in accordance with the qualitative research method, phenomenology pattern was used. In the research, the working group was determined in convenience sampling. Accordingly, 32 German teachers working in public and private high schools in the city center of Elazig in the 2016-2017 academic year, were included in the study group. The data of the research were collected through an interview form consisting of nine questions and prepared by the researchers. While creating the interview form, the literature was scanned, the content validity and expert opinion were taken into consideration. Descriptive analysis was used to analyze the data. While presenting the research findings, direct quotations from the opinions of the teachers were given. According to the research findings, teachers in the research stated the necessity of German as a second foreign language. The main problem faced by German teachers while using teaching methods and techniques is that they cannot get out of the ordinary. Teachers stated that the lack of adequate assessment and evaluation of the four basic language skills (listening, speaking, writing, reading) and the preference of written exams in measurement and evaluation as the main problem. Another problem is that the activities for the four basic language skills can not be done adequately. Students' reluctance has been expressed as another problem source. Teachers listed the lack of professional and motivational problems among themselves. In addition to this, it was revealed as a result of the research that there were some problematic situations arising from the parents' point of view.
\end{abstract}

\footnotetext{
* Bu çalışma Neslihan Durak Koç’un Ayşe Ülkü Kan'ın danışmanlığında hazırladığı “İkinci Yabancı Dil Olarak Almanca Öğretiminde Öğretmenlerin Karşılaştıkları Sorunlar” isimli yüksek lisans tezinden türetilmiştir.

Bu çalışma için Fırat Üniversitesi Girişimsel Olmayan Araştırmalar Etik Kurulundan onay alınmıştır (Evrak Tarih ve Sayıs1: 06/03/2018-251899)

** Dr. Öğr. Üyesi, Firat Üniversitesi, Eğitim Fakültesi, Eğitim Bilimleri Bölümü,

Asst. Professor, Firat University, Faculty of Education, Department of Educational Sciences

ORCID 0000-0002-1524-3326

aulkukan@yahoo.com

*** Yüksek Lisans Mezunu, Fırat Üniversitesi, Eğitim Bilimleri Enstitüsü, Eğitim Programları ve Öğretim Bilim Dalı Graduate Degree, Firat University, Graduate School of Educational Sciences, Division of Curriculum and Instruction ORCID 0000-0001-6639-6552

neslihandurak2@gmail.com

Cite as/ Atıf: Kan, A. Ü. \& Durak Koç, N. (2020). İkinci yabancı dil olarak almanca öğretiminde öğretmenlerin karşılaştıkları Sorunlar, $\quad$ Turkish Studies $\quad-\quad$ Education, $\quad 15(2), \quad$ 1025-1047. https://dx.doi.org/10.29228/TurkishStudies.39886

Received/Geliş: 24 November/Kasım 2019

Accepted/Kabul: 15 April/Nisan 2020

Copyright $(\mathrm{INTAC}$ LTD, Turkey 
Structured Abstract: The aim of this study is to examine the problems encountered by teachers in German teaching as second foreign language. This article presents solutions to the factors such as teachers, students, parents, assessment and evaluation in order to teaching the second foreign language as German more effective. Nine questions were asked to 32 German teachers to recognize these problems in this study. These questions:

1. What are the teachers' views on the necessity of teaching German as a second foreign language?

2. What are the teachers' views on the problems arising from the methods and techniques used in teaching German as a second foreign language?

3. What are the teachers' views on the problems arising from assesment and evaluation preferred in teaching German?

4. What are the teachers' views on the problems that arise with regard to in-class activities in teaching German?

5. What are the teachers' views on the problems arising from student in teaching German?

6. What are the teachers' views on the problems arising from teacher in teaching German?

7. What are the teachers' views on the problems arising from parents' perspective in teaching German?

8. What are the teachers' views on the problems arising from physical environment of the school in teaching German?

9. What are the suggestions of teachers to make German teaching as a second foreign language more effective?

Today, the decisions taken on foreign language education take into account the scientific, economic, political, social and cultural needs of countries in determining educational programs. Technological and economic developments in recent years have been influential in the field of foreign language education as in other fields. In the 21 st century, the importance of knowing and learning a foreign language has increased in order to catch such a rapidly changing technology. Nowadays, it is seen that one foreign language is not sufficient both in school and business life and second foreign language learning has become a necessity. As a matter of fact, it is emphasized that teaching German as a second foreign language is very important (Çelikkaya, 2013: 107). Moreover, recent studies reveal that bilingualism and multilingualism are becoming increasingly common in the world, especially in Europe. Hengirmen (2009: 24) recognizes the concept of bilingualism as an individual's ability to speak two languages equally. Foreign language teaching is an ongoing problem in our country. In practice, both the first foreign language teaching and the second language teaching have not yet reached the desired level. In this case, it is of great importance to determine the problems related to learning a foreign language and to find solutions to these problems.

The study group of research consists of 32 German teachers worked in high schools located in Elazı̆ city center, in 2016-2017 academic year. The study group consists of 18 female and 14 male German teachers. These German teachers work as 15 permanent teachers, 9 contractual teachers and 8 paid teachers. These teachers work in 26 public high schools and 6 private high schools of Ministry of National Education. Out of these teachers, 15 have 1-3 years of professional experience, 7 with 4-6 years of experience, 1 with 7-9 years of experience, and 9 with 10 years of experience. There are informations about the departments where German teachers graduated. Out of these German teachers, 19 graduated from the Faculty of Education and 13 from the Faculty of Humanity and Social Sciences. Phenomenology pattern which is a qualitative research design was used for this study. The sampling for qualitative data was determined through convenience sampling. The study data were collected through an interview form developed by the researchers. An interview form consists of nine questions. These questions in the interview form were designed by making a literature review and preparing the questions such as to provide content validity.

According to the research findings, German teachers stated the necessity of German language teaching as a second foreign language. The necessity of German language teaching was categorized under three headings: The necessity in terms of language and culture, the necessity in terms of carrier/technology/industry and the neccessity in terms of demand. German teachers emphasized need for second foreign language and being German as second important language in the necessity in terms of language and culture. The problems encountered by German teachers while using teaching method and techniques result from environmental 
factors and not break the routine. The lack of course materials was emphasized more the category of environmental problems. The problem with measurement and evaluation is that evaluation of language skills is inadequate and mostly written exams are used in this context. The main problem in terms of classroom tasks is stated as the lack of activities for four basic skills. While the indifference and unwillingness of students are another problem, especially professional illiteracy and lack of motivation of teachers are considered as problem status related to teachers. As the problem arising from parents' perspective, they do not find German beneficial. As the problem arising from physical environment of the school, it is stated as the lack of equipments and materials of the school. Besides this, German teachers emphasized the necessity of foreign language at every school. In order to minimize all these problematic situations, it has been seen that teachers within the scope of the research offer some formal suggestions on what to do in the formal dimension, what teachers and other stakeholders should do, and resources and materials.

The suggestions can be developed based on the research findings. The necesssity and importance of learning a foreign language should be expressed to students, teachers, parents and administrators. The pre-service trainig of foreign language teachers should be reviewed. The teachers should be trained in four basic skills. Foreing languages libraries can be created. The lessons hours in German should be reviewed. In these lessons hours, the activities based on four basic skills should be done.

Keywords: Educational Sciences, Teaching Foreign Language, German Teaching, German Teacher, Acquisition of Language.

Öz: Bu çalışma, ikinci yabancı dil olarak Almanca öğretiminde öğretmenlerin karşılaştıkları sorunları belirlemek amacıyla yapılmıştır. Nitel araştırma yöntemine uygun olarak yürütülen araştırmada, fenomenoloji deseni kullanılmıştır. Araştırmada çalışma grubu, kolay ulaşılabilir durum örneklemesine uygun olarak belirlenmiştir. Buna göre, 2016-2017 eğitim-öğretim yılında Elazığ il merkezindeki resmi ve özel liselerde görev yapan toplam 32 Almanca öğretmeni çalışma grubuna dâhil edilmiştir. Araştırmanın verileri, dokuz sorudan oluşan ve araştırmacılar tarafindan hazırlanan bir görüşme formu ile toplanmıştır. Görüşme formu oluşturulurken, alanyazın taraması yapılmıştır, kapsam geçerliği ve uzman görüşü dikkate alınmıştır. Verilerin çözümlenmesinde betimsel analiz kullanılmıştır. Araştırma bulguları sunulurken öğretmenlerin görüşlerinden doğrudan alıntılar verilmiştir. Araştırma bulgularına göre, araştırma kapsamındaki öğretmenler Almancayı ikinci yabancı dil olarak gerekli gördüklerini belirtmişlerdir. Almanca öğretmenlerinin öğretim yöntemtekniklerini kullanırken karşılaştıkları temel sorun, alışılmışın dışına çıkamamalarıdır. Öğretmenler, ölçme ve değerlendirmede dört temel dil becerisine (dinleme, konuşma, yazma, okuma) ilişkin yeterli ölçme değerlendirme yapılmaması ve daha çok yazılı sınavların tercih edilmesini, temel sorun olarak belirtmişlerdir. Bir diğer problem ise dört temel dil becerisine yönelik etkinliklerin yeterli düzeyde yapılamamasıdır. Öğrencilerin isteksizliği bir başka problem kaynağı olarak ifade edilmiştir. Öğretmenler, mesleki yetersizliği ve motivasyon eksikliğini ise kendilerine yönelik problemler arasında sıralamışlardır. Bunun yanında velilerin bakış açısından kaynaklı bazı problemli durumların olduğu da araştırma sonucunda ortaya çıkmıştır.

Anahtar Kelimeler: Eğitim Bilimleri, Yabancı Dil Öğretimi, Almanca Öğretimi, Almanca Öğretmeni, Dil Edinimi.

\section{Giriş}

İnsan toplumsal bir varlık olarak, çevresiyle sürekli irtibat halindedir. Anne karnında iletişim kurmaya başlayan birey, anadili ile birlikte yaşadığı toplumla bir bağ oluşturur. Yaşadığı ortama ve hızla dönüşen çağa ayak uydurmak için birey, anadil ile birlikte yabancı dil öğrenme ihtiyacı duyar. $\mathrm{Bu}$ ihtiyaç çoğu zaman birinci yabancı dil ile kalmayıp ikinci yabancı dilin öğrenilmesini de beraberinde getirebilir. Çünkü yabanc1 dil öğrenme süreci, farklı yer, ortam ve coğrafyalarda mevcudiyetini sürdüren ve dünyayı etkileyen bir takım ekonomik, sosyal, kültürel ve teknolojik durumlara uym gösterme ve bu bağlamdaki ihtiyaçları giderme gayreti şeklinde yorumlanabilir. Koçak ve Çobanoğulları' na (2017: 1) göre yabancı dil öğrenmek, bireylerin gerek sosyal gerek kültürel gerekse ekonomik hayatlarına önemli katkılar sağlamaktadır. Ancak bununla birlikte, dünya genelinde kabul gören İngilizcenin de yetersiz kaldığı ve değişen, dönüşen ihtiyaçlar doğrultusunda 
ikinci yabancı dil öğrenmenin bazı iletişimsel durumlarda gerekli görüldüğü belirtilmektedir. Yani siyasi, ekonomik ve sosyal etkileşim bağlamında öğretilen yabancı dillerin çeşitlendirilmesi; İngilizcenin yanında Almanca, Fransızca gibi başka batı dilleri de programlarda yer almıştır (Bür ve Aycan, 2013: 194). Çünkü 21. yüzyılda küreselleşmenin de etkisiyle bireylerin bir veya birden çok yabancı dili öğrenmesi neredeyse bir zorunluluk olmuştur (Ada ve Şahenk, 2010: 64)

Dil, kültürel birikimin ve mirasın nesillere aktarılmasında, duygu ve düşünce bağlamında bireylerin kaynaşmasında ve birbirleriyle iletişim kurmasında etkilidir. Modern çağda birey, en gelişmiş teknolojik unsurları ve ürünlerini hayatına dâhil ederek gelişim ve dönüşümünü tamamlma, refaha ulaşma ve mutluluk içinde yaşama arzusundadır. Bu bağlamda birey, aynı zamanda içinde yaşadığ 1 dönemin gerektirdiği bilgiye ve kaynaklara erişmenin bir yolu olarak, ana dilinden farklı dilleri de öğrenmeye ihtiyaç duyar hale gelmiştir. Bir iletişim aracı olarak dil, bireyin kendini anlatma ve başkalarını anlamadaki en önemli aracıdır. Dilin zenginleşmesi, insanın duygu ve düşünce olarak da geliştiğinin bir göstergesi olarak yorumlanabilir. Aksan (1999: 13) dili, iletişimde sözlü ve yazılı olarak kullanılan, dünyaya gelindiğinde hazır bularak edinmeye başlanılan, düşünme ve düşünüleni aktarma dizgesi olarak tanımlamıştır. Dili bir yeti olarak gören Chomsky (2009: 53) ise dilin, insanın biyolojik doğası gereği ortaya çıkan ve bütün kavrayışını etkileyen yapısına vurgu yapmaktadır.

Dil, bireyin çevresiyle iletişimini sağlayan bir araç olmanın ötesinde, onu toplum içinde var eden, çevresinde kabul görmesini sağlayan, farklı olanakların, iş imkânlarının ve eğitim kapılarının kendisine açılmasını sağlayan bir olgu haline gelmiştir. Bu bağlamda yabancı dil öğrenmenin hatta değişen ve dönüşen dünyada ikinci yabancı dil öğrnmenin gerekliliği kendini daha fazla göstermektedir. Günümüzde eğitim programları şekillendirilirken, yabancı dil eğitimi konusunda alınan kararlar ülkelerin farklı gereksinimlerine göre planlanmaktadır. Koçak ve Çobanoğulları' nın (2017: 1) da belirttiği gibi ikinci yabancı dil öğretiminin sadece çalışma hayatına dâhil olma ya da iletişimsel artılar sağlama dışında, Avrupa Birliği hedefinin gerçekleşmesi ve bu hedefle uyumluluk noktasında da katkıları olacaktır. Son yıllarda, teknolojik ve ekonomik bağlamda meydana gelen gelişmeler, farklı mecralarda olduğu gibi, yabancı dil eğitiminde de etkili olmuştur. 21. yüzyılda gerçekleşen hızlı değişim ve dönüşüm süreçlerini yakalamak için yabancı dil bilmenin ve öğrenmenin önemini kavramak gerekir. Gelinen dönemde gerek eğitim hayatında gerekse iş hayatında tek bir yabancı dil öğrenmenin yeterli olmadığı fikri kabul görmektedir. Bu durum, ikinci yabancı dil öğrenimini daha önemli hale getirmektedir. Nitekim yapılan bazı araştırmalara göre Almancanın, ikinci yabancı dil olarak öğretilmesinin oldukça önemli olduğu vurgulanmıştır (Çelikkaya, 2013: 107). Dünyada özellikle Avrupa'da ikidillilik ve çokdillilik giderek yaygınlaşmaktadır. İki dillilik, bireyin iki dili birbiriyle aynı oranda bilmesi veya bulunduğu ortamda zorlama olmadan rahat bir şekilde konuşabilmesi olarak tanımlanmaktadır (Hengirmen, 2009: 24). Güzel (2014:76), bu kavramı, bireyin yabanc1 bir ülkede konuşulan dili, anadil düzeyinde kullanması; dili kullanırken de dilin kültürünü tanıması şeklinde açıklamıştır. Benzer biçimde Tokdemir (1997:42) de iki dilliliği açıklarken, iki dilin anadil düzeyinde konuşulması ve her iki dilin doğumdan itibaren öğrenilmesi yönüne vurgu yapmıştır.

\section{Türkiye'de İkinci Yabancı Dil Öğretimi}

Ülkemizde eğitim alanında yapılan bazı düzenleme ve değişiklikler yabancı dil öğrenme ve kullanmaya duyulan ihtiyacın farkına varıldığı göstermektedir. Ancak bu bağlamda, yabancı dil vurgusunun akla ilk olarak İngilizceyi getirdiği söylenebilir. Benzer durumu vurgulayan Gündoğdu (2005: 123), İngilizcenin etki alanının genişliği nedeniyle diğer yabancı dillerin eğitim programlarda yeterince yer alamadığını belirtirken benzer biçimde Can ve Can (2014: 44) da ikinci yabancı dil olarak Almanca ve Fransızca'nın öğretimde dikkate alındığı; ancak birinci yabancı dil olarak kabul gören İngilizce önemsenmediğini ifade etmiştir. Almanca öğretimi İngilizce gibi daha küçük yaş gruplarında değil, lise düzeyinde başlamaktadır. Akıllılar (2013: 276), yabancı dil öğretimi konusunda İngilizcenin daha öncelikli olarak akla gelmesini sürdürülen yabancı dil öğretiminin 
çokdillilik çerçevesinde yürütülmemesine bağlamaktadır. Bununla birlikte İngilizceden sonra ikinci yabancı dil olarak öğretilen diller arasında Almanca ilk sıraya oturmaktadırr (Gündoğdu, 2005: 124)

Karaman (2017:106), erken yaşta ikinci yabancı dil öğrenmenin çocuğa, dil- kültür bağlamında empati kurma, farklılıklara saygı duyma, hoşgörülü olma gibi daha sonraki yaşamına katk1 sağlayacak kazanımları elde etme imkanı sunacağını belirtmiştir. Yabancı dil öğretimi ülkemizde süregelen sıkıntılı bir durumdur. Hem birinci hem ikinci yabancı dil öğretiminde henüz istenilen, beklenen seviyeye ulaşılamamıştır. Birinci yabancı dil öğretimi ile ilgili problemler halledilememişken, farklı bir yabancı dilin öğretimi daha büyük problemlerle varlığını göstermektedir. Buna göre yabancı dil öğrenmeye ilişkin problemlerin belirlenmesi ve bu belirlenen problemlelre çözüm yollarını üretmek önem arz etmektedir.

Türkiye-Avrupa Birliği ilişkilerinin geliştirilmesi için, uyum çalışmaları yapılmıştır. Bu uyum çalışmaları MEB'in Yabancı Dil Eğitimi ve Öğretimi Yönetmeliği'ne de yansımıştır. Bu yönetmeliğin ilgili maddesine göre, ilköğretim kurumlarında 4. sınıftan itibaren zorunlu yabancı dil derslerine yer verilemesi, aynı sınıf düzeyinden itibaren zorunlu yabancı dil dersinin takviyesi ya da ikinci yabancı dil dersi olarak seçmeli dil derslerine yer verilebileceği; bunun yanında tüm sınıflarda ise ders saatleri dışında yabancı dil yetiştirici kursları verilebileceği belirtilmiştir (MEB, 2006a). Bununla birlikte yapılan düzenlemeyle, yabancı dil derslerinin, ilkokul 2.- 4. sınıflarda haftada ikişer saat, ortaokul 5.-8. Sınıflarda ise haftada dörder saat okutulacağı açıklanmıştır. Bu düzenlemeye göre yabancı dil öğretimi iki yıl öne alınmıştır (MEB, 2012: 24-25). Ortaöğretim kurumlarında verilen yabancı dil dersi ile ilgili olarak ise Millî Eğitim Bakanlığı'nın Yabancı Dil Eğitimi ve Öğretimi Yönetmeliğine göre, ilköğretimdeki yabancı dil ders programlarının devamı olarak, birinci yabancı dil ve kurulca uygun görülen okullarda zorunlu ikinci yabancı dil derslerine yer verilmesi; bunun yanında zorunlu yabancı dil derslerinin takviyesi amacıyla seçmeli yabancı dil derslerine de yer verilebileceği ve bu bağlamda bütün sınıflarda ders saatleri haricinde öğrencilerin düzeylerine uygun olarak yabancı dil yetiştirici kurs programları uygulanabileceği vurgulanmıştır (MEB, 2006a).

Nitekim yabancı dil eğitiminin ve öğretiminin amacı, Milli Eğitimin amaçaları paralelinde, ilgili okul ya da kurumun amaç ve seviyeleri de dikkate alınarak; bireylerin yabancı dille, temel dil becerilerini kazanmalarını, iletişim kurmalarını ve o dile ilişkin olumlu tutum geliştirmelerini sağlamak olarak ifade edilmiştir (MEB, 2006a). Buna göre hem temel dil becerilerinin hem de öğrenilecek yabancı dile ilişkin olumlu tutum geliştirmenin dil edinimi açısından ne denli önemli olduğu vurgulanabilir. "Genel Liselerin Anadolu Liselerine Dönüştürülmesi” genelgesiyle (MEB, 2010), Türkiye'deki düz liseler, aşamalı olarak Anadolu Liselerine dönüştürülme sürecine girmiştir. $\mathrm{Bu}$ dönüșüm çalıșmaları neticesinde 7 Eylül 2013 tarihli Resmî Gazetede yeni "Millî Eğitim Bakanlığı Ortaöğretim Kurumları Yönetmeliği yayınlamıștır (Resmi Gazete, 2013). Yönetmeliğin ilgili maddesinde dil becerilerine ve kazanımlara uygun eğitim verilmesine vurgu yapılmıştır.

Ortaöğretim Kurumları 10, 11 ve 12. Sinıf İkinci Yabanc1 Dil Almanca Dersi Programı (MEB, 2006b: s.3-5), incelendiğinde, programdaki kazanımların, dört dil becerisi ve öğrenci merkezli yaklaşıma göre düzenlemesine vurgu yapıldığı görülmektedir. Bunun yanında iletişimsel yaklaşımın temel alınması, tanıma, anlama, sorgulama, sıralama, sınıflama, özetleme, ilişkilendirme ve eşleştirme gibi alt becerilerin de dört temel beceriyle birlikte kazandırılmasının esas alınması gerektiği belirtilmiştir. MEB Talim ve Terbiye Kurulu Başkanlığı'nın 19 Aralık 2018 tarihli 56 sayılı Ortaöğretim Kurumları Haftalık Ders Çizelgesi konulu yazısında da haftalık olarak 9-12. sınıflarda ikişer saat ikinci yabancı dil dersi verilmesi ifadesi bulunmaktadır. Ayrıca hazırlık sınıfı olması halinde ikinci yabancı dil dersinin haftalık dört saat olarak verilmesi uygun görülmüştür (MEB, 2018).

Resmi olarak sınırları çizilmiş Almanca öğretiminde, okullarda bir takım sıkıntılı durumlar yaşanması olasıdır. Dünyada öğrenilme oranı yüksek olan Almanca, ülkemizde ikinci yabancı dil olarak öğretim programlarında yer almaktadır. Ancak ülkemizde öğrencilerin büyük oranının 
Almancayı yeterli seviyede öğrenemedikleri hatta başlangıç düzeyi olarak dahi sıkıntılar yaşandığı belirtilmektedir (Koçak ve Çobanoğulları, 2017: 2). Her ne kadar ülkemizde birinci yabancı dil olarak algılanan İngilizcenin olumlu transfer yoluyla ikinci yabancı dil olarak algılanan Almancanın öğrenilmesini kolaylaştırabileceğine ilişkin görüşler olsa da (Akıllılar, 2013: 283) öğretmenlerin, Almancanın ikinci yabancı dil olarak öğretiminde bazı problemlerle karşılaşabilecekleri düşünüldüğ̈̈nden ve alanyazında bu konuyla alakalı çok fazla çalışmaya rastlanmadığı için durumun nitel boyutta araştırılması gerekli görülmüş ve böyle bir çalışma yapılmıştır. Bu bağlamda öğretmenlerin sürece ilişkin görüşlerinin alınması ve bu görüşler ışı̆̆ında duruma katkı sağlayacağ düşünülen önerilerin geliştirilmesi hedeflenmiştir. Bu araştırmanın amacı, ikinci yabancı dil olarak Almanca öğretiminde öğretmenlerin karşılaştıkları zorlukları belirlemektir. Bu bağlamda araştırma kapsamındaki öğretmenlerin görüşlerini almak üzere şu sorulara yanıtlar aranmıştır.

Öğretmenlerin,

- İkinci yabancı dil olarak Almanca öğretiminin gerekliliğine,

- İkinci yabancı dil olarak Almanca öğretiminde kullanılan yöntem ve tekniklerden kaynaklanan sorunlara,

- Almanca öğretiminde tercih edilen ölçme ve değerlendirmeden kaynaklanan sorunlara,

- Almanca öğretiminde yürütülen ders içi etkinliklere yönelik oluşan sorunlara,

- Almanca öğretiminde öğrenciden kaynaklanan sorunlara,

- Almanca öğretiminde öğretmenden kaynaklanan sorunlara,

- Almanca öğretiminde velilerin bakış açısından kaynaklanan sorunlara,

- Almanca ögretiminde okulun fiziksel imkânlarından kaynaklanan sorunlara,

- İkinci yabanci dil olarak Almanca öğretiminin daha etkili olabilmesi için önerilerine ilişkin görüşleri nelerdir?

\section{Yöntem}

$\mathrm{Bu}$ çalışmada, nitel araştırma yöntemi ve fenomenoloji deseni kullanılmıştır. Bu desen tümüyle yabancı olunmayan ancak tümüyle kavranamayan durum ya da olguların araştırılmasında kullanılır (Yıldırım ve Şimşek, 2016: 69). Fenomenoloji çalışmalarında en belirgin veri toplama aracı görüşmedir. $\mathrm{Bu}$ çalışmada da veriler görüşme yoluyla toplanmıştır. Araştırma yürütülmeye başlamadan önce Frrat Üniversitesi/Girişimsel Olmayan Araştırmalar Etik Kurulundan etik kurul raporu (Evrak Tarih ve Sayısı: 06/03/2018-251899) alınmıştır. Bu bağlamda etik kurallara riayet edilerek çalışma yürütülmüş ve katılımcılarla görüşmeler yapılmıştır.

\section{Çalışma Grubu}

Araştırmada kolay ulaşılabilir durum örneklemesi kullanılmıştır. $\mathrm{Bu}$ örnekleme türü, araștırmacının kendisine yakın ve kolaylıkla ulaşabileceği durumu seçmesi olarak ifade edilmektedir (Yıldırım ve Şimşek, 2016). 2016-2017 eğitim-öğretim yılında Elazı̆̆ merkezindeki özel ve resmi liselerde ücretli, sözleşmeli ve kadrolu, olarak çalışan 37 Almanca öğretmeni araştırmanın çalışma grubunu oluşturmaktadır. Çalışmaya katılımda gönüllülük dikkate alınmıştır. Görüşme için okullara gidildiğinde iki Almanca öğretmenin yurt dışında olduğu, bir öğretmenin de izinli olduğu görülmüştür. İki öğretmen de araştırmaya katılmaya gönüllü olmadığı için 5 öğretmen araştırma dış1 tutulmuştur ve 32 öğretmenden konuya ilişkin görüş alınmıştır. Çalışma grubuna ilişkin bazı bilgiler Tablo 1'de sunulmuştur: 
Tablo 1: Almanca Öğretmenlerine İlişkin Bilgiler

\begin{tabular}{cccc}
\hline \multirow{2}{*}{ Değişkenler } & & f & \% \\
\hline \multirow{2}{*}{ Cinsiyet } & Kadın & 18 & 56,25 \\
\cline { 2 - 4 } Okul Türü & Erkek & 14 & 43,75 \\
\cline { 2 - 4 } & Resmi & 26 & 81,25 \\
\cline { 2 - 4 } & Özel & 6 & 18,75 \\
\cline { 2 - 4 } Mesleki Tecrübe & $1-3$ yıl & 15 & 46,88 \\
\cline { 2 - 4 } & $4-6$ yıl & 7 & 21,88 \\
\cline { 2 - 4 } & $7-9$ yıl & 1 & 3,13 \\
\hline \multirow{2}{*}{ Mezun Olduğu Bölüm } & 10 yıl ve üstü & 9 & 28,13 \\
\cline { 2 - 4 } & Ĕgitim Fakültesi & 19 & 59,38 \\
\hline \multirow{2}{*}{$\begin{array}{c}\text { İnsani ve Sosyal Bilimler Fakültesi } \\
\text { Kadrolu Öğretmen }\end{array}$} & 13 & 40,63 \\
\cline { 2 - 4 } Öğretmenlik Türü & Sözleşmeli Öğretmen & 9 & 28,13 \\
\cline { 2 - 4 } & Ücretli Öğretmen & 8 & 25,00 \\
\hline
\end{tabular}

Araştırma Elazığ il merkezinde bulunan 32 okulda yürütülmüştür. 2016-2017 eğitim-öğretim yılında görev yapan 18 kadın, 14 erkek toplam 32 öğretmen araştırmaya dâhil olmuştur. 32 öğretmen, Öğretmenlerin 15'i kadrolu, 9'u sözleşmeli ve 8'i ücretli olarak görev yapmaktadır. Mesleki tecrübe dikkate alındığında 1-3 yıl arasında 15, 4-6 yıl arasında 7, 7-9 yıl arasında 1; 10 yıl ve üstünde ise 9 öğretmen çalışma grubunda yer almıştır. Öğretmenlerin mezun oldukları bölümlere göre dağılımlarına bakıldığında ise Eğitim Fakültesinden 19, İnsani ve Sosyal Bilimler Fakültesinden (Fen-Edebiyat Fakültesi) ise 13 öğretmenin olduğu görülmüsştür.

\section{Verilerin Toplanması}

Araştırmada veriler, görüşme yoluyla toplanmıştır. Görüşme ile deneyimler, tutumlar, algılar, tepkiler gibi durumlar anlaşılmaya çalışılır (Yıldırım ve Şimşek, 2016: 130). Görüşme yaparak, bireylerin bazı konulardaki bilgilerini, düşüncelerini, tutum ve davranışlarını ve bunların gerisinde yatan nedenleri en kisa yoldan ortaya koymak mümkündür (Karasar 2016:120). Araştırmada yapılandırılmış görüşme kullanılmıştır. Görüşmelerin gerçekleştirilmesi için araştırmacılar tarafından hazırlanan bir form kullanılmıştır. Görüşme formu hazırlanırken önce bir soru havuzu oluşturulmuştur. Bu soru havuzu oluşturulurken araştırmanın amaçlarına da uygun olarak hem alanyazın taraması hem de kapsam geçerliği dikkate alınmıştır. Hazırlanan sorular listesi Eğitim Bilimleri Bölümünde görev yapan bir profesör ve bir doktor öğretim üyesi, farklı şehirlerde görevini yürüten üç Almanca öğretmeni ve üç Türkçe öğretmeninin görüşleri doğrultusunda dil, şekil ve kapsam açısından düzenlenerek toplam dokuz sorudan oluşan nihai bir görüşme formu elde edilmiştir. Öğretmenlerle yüzyüze görüşme yapılarak ses kaydı alınması planlanmıştır. Bazı öğretmenler ses kaydı vermek istemedikleri için aynı sorular görüşme formu şeklinde uygulanmış ve araştırmanın verileri toplanmıştır. 


\section{Verilerin Analizi}

Araştırmada veriler çözümlenirken betimsel analiz kullanılmıştır. Betimsel analiz, görüşmeler, gözlemler sonucu ulaşılan verilerin sistematize edilmiş ve yorumlanmış bir biçimde okuyucuya aktarılması sürecidir (Karataş, 2015: 67). Betimsel analizde çözümleme önceden belirlenen temalar çerçevesinde şekillendirilir (Yıldırım ve Şimşek, 2016: 239). Nitel araştırmalarda geçerliğin sağlanmasındaki yollardan biri verilerin raporlaştırılma sürecinin ayrıntılı biçimde anlatmasıdır (Yıldırım ve Şimşek, 2016:270). Yazım aşamasında bu ilkeye uyulmuştur. Yine bu süreçte araştırma sonuçlarının teyit edilebilir olması da önemlidir (Yıldırım ve Şimşek, 2016:275). Çözümleme sürecinde iki araştırmacı birlikte çalışmıştır. Görüş birliği sağlanan ve sağlanamayan kodlamalar belirlenerek Miles-Hubermann (1994) formülü kullanılmış ve hesaplama yapılmıştır. Görüş birliği ve görüş ayrılığı dikkate alınarak yapılan güvenirlik hesaplamasında güvenirlik düzeyi \%84'tür. Bulgular sunulurken araştırma kapsamındaki öğretmenlerin cümlelerinden doğrudan alıntılar yapılmıştır. Doğrudan alıntılar italik yazı karakteriyle ve tırnak içinde verilmiştir. Her doğrudan alıntının başına katılımcının çözümleme sürecinde verilen numarası ve cinsiyetini gösteren harf eklenmiştir.

\section{Bulgular}

Bu bölümde, çalışmanın bulguları tablolar halinde sunulmuştur.

\section{Öğretmenlerin İkinci Yabancı Dil Olarak Almanca Öğretiminin Gerekliliğine İlişskin Görüşleri} sunulmuştur.

İkinci yabancı dil olarak Almancanın gerekliliğine ilişkin görüşler Tablo 2'de

Tablo 2: İkinci Yabancı Dil Olarak Almanca Öğretiminin Gerekliliğine İlişkin Görüşler

\begin{tabular}{|c|c|c|c|}
\hline Temalar & Alt Temalar & & $\mathrm{f}$ \\
\hline \multirow{8}{*}{ Gerekli görme } & \multirow{4}{*}{$\begin{array}{l}\text { Dil ve kültür boyutundaki } \\
\text { gereklilik }\end{array}$} & $\begin{array}{l}\text { İkinci yabancı dile duyulan } \\
\text { ihtiyaç }\end{array}$ & 12 \\
\hline & & İkinci önemli dil olması & 12 \\
\hline & & Dünya ülkeleri ile olan diyalog & 7 \\
\hline & & $\begin{array}{l}\text { En çok konuşulan diller } \\
\text { arasında olması }\end{array}$ & 2 \\
\hline & \multirow{3}{*}{$\begin{array}{l}\text { Kariyer/teknoloji/sanayi } \\
\text { boyutundaki gereklilik }\end{array}$} & Mesleki gelişim & 5 \\
\hline & & Teknolojik gelişmeler & 4 \\
\hline & & Sanayileşme & 3 \\
\hline & \multicolumn{2}{|l|}{ Talepten doğan gereklilik } & 1 \\
\hline \multicolumn{3}{|c|}{ Gerekli görmeme } & 2 \\
\hline
\end{tabular}

Öğretmenlerin ikinci yabancı dil olarak Almancanın gerekliliğine ilişkin görüşleri Tablo 2'de özetlenmiştir. Araştırma kapsamındaki öğretmenlerin büyük bir kısmı, Almancayı gerekli görürken, bazı öğretmenler gerekli bulmadıklarını belirtmişlerdir. Almancayı ikinci yabancı dil olarak gerekli gören katılımcıların görüşlerine bakıldığında bunların; dil/kültür, kariyer/teknoloji/sanayi ve talepten doğan gereklilik boyutlarında yoğunlaştığı görülmüştür. Dil ve kültür boyutu için katılımcıların görüşleri; ikinci yabancı dile olan ihtiyaç, Almancanın ikinci önemli dil olması, dünya ülkeleri ile olan kültür/diyalog ve Almancanın en çok konuşulan diller arasında 
olması olarak belirlenmiştir. Kariyer/teknolojik/sanayi boyutu için katılımcılar; mesleki gelişim, teknolojik gelişmelere ve sanayileşmeye değinmişlerdir. Araştırma kapsamındaki öğretmenlerin görüşlerinden örnek cümleler aşağıda sıralanmıştır:

(Ö-25-k) “....günümüzde bir yabancı dil bilmek zorunluluk iken ikinci yabancı dil öğrenmek gerek iş hayatında gerek toplumsal hayatta insanlar için ayrıcalıktır. Almanca bu nedenle önemlidir..."

(Ö-17-k) “....Almanya ile ticari ilişkilerimizin geliştiği düşünülebilir. Bunun için Almanca öğrenme konusunda daha istekli olmalıyız."

(Ö-15-e) “.....Almanca farklı kültürlerdeki insanları tanımak için gereklidir çünkü, dünyada en çok konuşulan dillerden biridir...."

(Ö-3-e), “....farklı ülkeler ile diyaloğa geçmek istenirse bu dili(Almancayı) öğrenmemiz şart, kişi üniversitede hangi bölümü okursa okusun ikinci yabancı dili de öğrenmelidir ve Almanca tercih edilmesi gereken dillerden biridir...."

(Ö-10-k), “.....iş hayatında ikinci yabancı dil artık neredeyse zorunluluktur, böyle bir dönemde Almanca öğretimi gerekliliktir bence...."

(Ö-14-k), “....değişen teknoloji ve ticari ilişsilerin gelişimi doğrultusunda Almanca öğrenmenin yaygınlaşması gerektiğini düşünüyorum....."

(Ö-4-e) “...Almanya'nın sanayi ülkesi olması ve Almanya-Türkiye ticari ilişkileri dikkate alınırsa bu dil (Almanca), ikinci öğretilen yabancı diller listesinde en başı almalıdır...." olur..."

(Ö-27-e), “....bence bütün okullarda gerekli değil, talep edilmesi halinde öğretilse daha iyi

(Ö-6-e) “....İngilizce öğretiminde yaşanan bu kadar sorun varken ikinci dil öğretiminin gereksiz olduğunu düşünüyorum...."

\section{Öğretmenlerin Almanca Öğretiminde Kullanılan \\ Yöntem ve Tekniklerden Kaynaklanan Sorunlara İlişkin Görüşleri}

Tablo 3'te öğretmenlerin Almanca öğretiminde kullanılan öğretim yöntem-tekniklerinden kaynaklanan sorunlara ilişkin görüşlerine yer verilmiştir. 
Tablo 3: Kullanılan Yöntem ve Tekniklerden Kaynaklanan Sorunlara İlişkin Görüşler

\begin{tabular}{|c|c|c|c|}
\hline Temalar & Alt Temalar & & f \\
\hline \multirow{7}{*}{ Sorun olması } & \multirow{3}{*}{$\begin{array}{l}\text { Çevresel etmenlerden } \\
\text { kaynaklı sorunlar }\end{array}$} & $\begin{array}{l}\text { Kaynak ve materyallerin yetersiz } \\
\text { olmasi }\end{array}$ & 10 \\
\hline & & Ders saatinin yetersiz olmas1 & 4 \\
\hline & & Sınıf koşullarının uygun olmaması & 1 \\
\hline & \multirow{4}{*}{$\begin{array}{l}\text { Alışılmışın } \\
\text { çıkamamaktan } \\
\text { sorunlar }\end{array}$} & $\begin{array}{l}\text { Dilbilgisi-çeviri } \\
\text { kullanılması }\end{array}$ & 4 \\
\hline & & $\begin{array}{l}\text { Konuşma becerisinin öncelikli } \\
\text { olmaması }\end{array}$ & 4 \\
\hline & & $\begin{array}{l}\text { Geleneksel yöntem/tekniklerin } \\
\text { tercih edilmesi }\end{array}$ & 4 \\
\hline & & $\begin{array}{l}\text { Hedef kitleye uygun yöntem ve } \\
\text { tekniğin kullanılmaması }\end{array}$ & 3 \\
\hline \multicolumn{2}{|c|}{ Sorun olmaması } & & 2 \\
\hline
\end{tabular}

Öğretim yöntem ve tekniklerinden kaynaklanan sorunlara ilişkin görüşler dikkate alındığında, hem birtakım sorunlara vurgu yapıldığı hem de sorun olmadığını düşünen öğretmenlerin olduğu görülmüştür. Sorun olduğuna ilişkin görüşler, çevresel etmenlerden kaynakl1 sorunlar ve alışılmışın dışına çıkamamaktan kaynaklı sorunlar şeklinde iki ayrı kategoride toplanmıştır. Çevresel etmenlerden kaynaklı sorunların; kaynak ve materyallerin yetersiz olmas1, ders saatlerinin yetersiz olması ve sınıf koşullarının uygun olmaması şeklinde sıralandığı görülmektedir. Alışılmışın dışına çıkamamaktan kaynaklı sorunlar ise dil bilgisi-çeviri metodunun kullanılması, konuşma becerisinin öncelikli olmaması, geleneksel yöntem/tekniklerin tercih edilmesi ve hedef kitleye uygun yöntem ve tekniğin kullanılmaması şeklinde sıralanmıştır. Kodlamalara kaynaklık eden görüşlerden örnekler aşağıda sıralanmıştır:

(Ö-21-e) “.....öğretim materyallerinin çok iyi hazırlanmadığı düşünüyorum...”

(Ö-20-k) “...görsel-işitsel teknikleri kullanmak isin ders kitapları yeterli düzeyde değil...”

(Ö-2-e) “...ders saatinin yetersizliğinden çoğu öğretim yöntem ve tekniklerini kullanamiyoruz..."

(Ö-3-e), “....dil bilgisi-çeviri metodunun kullanılması bazı eksikliklere neden oluyor, ana dil nasıl veriliyorsa yabancı dil de öyle öğretilmeli;konuşma becerisi öncelenmelidir sonrasında da gramer öğretilmelidir.”

(Ö-19-k) “...öğretmen, sınıfa girdiği andan itibaren öğrenciyi konuşmaya cesaretlendirmeli, teşvik etmeli, ancak bunu çoğu zaman yapmıyoruz..."

(Ö-17-k) “....sadece düz anlatım yöntemi kullanılarak yürütülen dersler büyük eksikliğimiz..."

\section{Öğretmenlerin Almanca Öğretiminde Tercih Edilen}

\section{Ölçme ve Değerlendirmeden Kaynaklanan Sorunlara İlişkin Görüsşleri}

Tablo 4'te Almanca ögretiminde tercih edilen ölçme ve değerlendirmeden kaynaklanan sorunlara ilişkin görüşlere yer verilmiştir. 
Tablo 4: Tercih Edilen Ölçme ve Değerlendirmeden Kaynaklanan Sorunlara İlişkin Görüşler

\begin{tabular}{lll}
\multirow{3}{*}{ Temalar } & Alt Temalar & $\mathrm{f}$ \\
\hline \multirow{3}{*}{ Sorun olması } & $\begin{array}{l}\text { Dil becerilerine ilişkin yeterli ölçme- } \\
\text { değerlendirmenin yapılmaması }\end{array}$ & 15 \\
\cline { 2 - 3 } & Yazılı sınav kullanılması & 10 \\
\cline { 2 - 3 } & Öğrenci motivasyonunu olumsuz etkilemesi & 3 \\
\cline { 2 - 3 } & Öğretmenlerin yeterli donanıma sahip olmaması & 1 \\
\hline Sorun olmaması & & 7 \\
\hline
\end{tabular}

Almanca öğretmenlerinin büyük çoğunluğu ölçme-değerlendirmede sorun olduğunu vurgularken, yedi öğretmen bu hususta sorun görmediklerini belirtmiştir. Sorun olduğunu düşünen öğretmenler; dil becerilerine ilişkin yeterli ölçme-değerlendirmenin yapılmaması, yazılı sınav kullanılması, ölçme-değerlendirmenin öğrenci motivasyonunu olumsuz etkilemesi ve öğretmenlerin yeterli donanıma sahip olmamasına vurgu yapmışlardır. Bu bağlamda kodlamalara kaynaklık eden doğrudan alıntılar aşağıda sıralanmıştır:

(Ö-8-k) “...kaynaklarımız gramer ağırlıklı, dört temel beceriye hitap etmiyor bu nedenle uygun ölçme-değerlendirme yapamıoruz...”

(Ö-24-k) “...ölçme-değerlendirmede yazılı sınav olması manasız, yabancı dil konuşarak öğrenilir bu yüzden ölçme-değerlendirmenin de konuşmaya uygun olması gerekir..."

(Ö-10-k) “...ölçme-değerlendirmenin yazılı sınavla yapılması öğrenciye yeterli geri bildirim verilememesine neden oluyor; bu da motivasyonu kötü etkiliyor"

(Ö-14-k) “...öğretmenler, ölçme-değerlendirme konusunda yeterince bilgi sahibi değiller.”

(Ö-28-k) “....açıkçası özel okullarda ölçme-değerlendirmeye ilişkin herhangi bir sorun göremiyorum..." demiştir.

\section{Öğretmenlerin Almanca Öğretiminde Yürütülen Etkinliklerdeki Sorunlara İliş̧kin Görüşleri}

Tablo 5'te öğretmenlerin Almanca öğretiminde yürütülen ders içi etkinliklere yönelik sorunlara ilişkin görüşlerine yer verilmiştir.

Tablo 5: Öğretmenlerin Almanca Öğretiminde Yürütülen Etkinliklerdeki Sorunlara İlişkin Görüşleri

\begin{tabular}{|c|c|c|c|}
\hline Temalar & Alt Temalar & & $\varepsilon$ \\
\hline \multirow{4}{*}{$\begin{array}{l}\text { Öğretmenden } \\
\text { kaynakl1 } \\
\text { sorunlar }\end{array}$} & \multirow{3}{*}{$\begin{array}{l}\text { Dört temel beceriye yönelik } \\
\text { etkinlik yapılamaması }\end{array}$} & Ders saatinin yetersizliği & 12 \\
\hline & & $\begin{array}{l}\text { Sinif mevcudunun } \\
\text { kalabalık olmasi }\end{array}$ & 7 \\
\hline & & $\begin{array}{l}\text { Dilin kullanımın sınırlı } \\
\text { olması }\end{array}$ & 6 \\
\hline & \multicolumn{2}{|c|}{ Dört beceriyi kullanmadaki yetersizlik } & 1 \\
\hline \multirow{2}{*}{$\begin{array}{l}\text { Öğrenciden } \\
\text { kaynaklı } \\
\text { sorunlar }\end{array}$} & \multicolumn{2}{|l|}{ Motivasyon eksikliği } & 7 \\
\hline & \multicolumn{2}{|c|}{ Yapılan etkinliklerinin anlaşılamaması } & 3 \\
\hline
\end{tabular}


Öğretmenlerin Almanca öğretiminde yapılan sınıf içi etkinliklerde yaşadıkları problemlere ilişkin görüşleri incelendiğinde öğretmenden kaynaklı ve öğrenciden kaynaklı sorunlar olmak üzere iki temanın oluştuğu görülmüştür. Öğretmenden kaynaklı sorunlar, dört beceriyi kullanmadaki yetersizlik ve dört temel beceriye yönelik etkinlik yapılamaması olarak sıralanmıştır. Aynı zamanda dört temel beceriye yönelik etkinlik yapılamaması için öğretmenlerin; ders saatinin yetersizliği, sınıf mevcudunun kalabalık olması ve dilin kullanımının sınırlı olması gibi konular üzerinde durdukları görülmüştür. Öğrenciden kaynaklı sorunlar için ise motivasyon eksikliği ve yapılan etkinliklerin anlaşılamamasına vurgu yapılmıştır. Bu durumlara ilişkin doğrudan alıntılardan örnekler aşağıda sıralanmıştır:

(Ö-2-e) “...bence ders saatleri yetersiz, bundan dolayı temel dört beceriye yeterli zaman ayıramiyoruz..."

(Ö-5-k) “...sinıflaın kalabalık olmasından dolayı zaman sorunu yaşanıyor, bu nsebeple de etkinlikler istediğimiz gibi olamıyor çoğu zaman...." göstermiyor...."

(Ö-2-e) “...öğrencinin, bu dili nerede kullanacağına ilişkin kafası karışık, bu sebeple ilgi

(Ö-31-k) “...alınan eğitimden kaynaklı olarak öğretmenlerin de bazen dinleme-konuşma becerilerinde yetersiz kaldıkları olabiliyor..."

(Ö-4-e) “...dört temel beceriden konuşma becerisine ilişkin etkinliklerde öğrenci ürkek davranabiliyor ...."

(Ö-3-e), “...özellikle yazma ve okuma becerilerinde maalesef öğrenciler sıkılıyor, çok istekli değiller...”

(Ö-29-e) "...Almancada birden fazla harfin yan yana gelmesi ve bu harflerin Türkçede bir tek sese denk gelmesi öğrencileri zorlayabiliyor, kafa karışıklığı yaratıyor..."

\section{Öğretmenlerin Almanca Öğretiminde Öğrenciden Kaynaklanan Sorunlara İlişkin Görüsşleri}

Tablo 6'da öğretmenlerin Almanca öğretiminde öğrenciden kaynaklanan sorunlara ilişkin görüşlerine yer verilmiştir.

Tablo 6: Öğrenciden Kaynaklanan Sorunlara İlişkin Görüşler

\begin{tabular}{lll}
\hline \multirow{2}{*}{ Temalar } & \multicolumn{1}{c}{ Alt Temalar } & $\mathrm{f}$ \\
\hline \multirow{3}{*}{$\begin{array}{l}\text { Öğrencinin } \\
\text { ilgisizliği/isteksizliği }\end{array}$} & Sinav sisteminde soru sorulmaması & 6 \\
\cline { 2 - 3 } & Dilin kullanımının sınırlı olması & 5 \\
\cline { 2 - 3 } & Öğrencinin motivasyon eksikliği & 5 \\
\cline { 2 - 3 } & Dersin kredisinin düşük olması & 1 \\
\hline \multirow{3}{*}{ Yabancı dili öğrenememesi } & Ana dilin doğru kullanılmaması & 3 \\
\cline { 2 - 3 } & Dili öğrenemeyeceği kaygısı & 3 \\
\cline { 2 - 3 } & Almancanın lise düzeyinde başlaması & 2 \\
\cline { 2 - 3 } & Yabancı dili içselleştirememesi & \multirow{2}{*}{1} \\
\hline Yabancı dilin önemini kavrayamaması & 9 \\
\hline
\end{tabular}

Almanca öğretiminde öğrenciden kaynaklanan sorunlar Tablo 6'da sunulmuştur. Öğretmenler bu sorunlar için öğrencilerden kaynaklı; ilgisizlik/isteksizlik, yabancı dili öğrenememe, 
yabanc1 dilin önemini kavrayamama gibi durumlara vurgu yapmışlardır. Öğrencinin ilgisizliği/isteksizliğine ilişkin nedenler, sınav sisteminde Almancadan soru sorulmaması, Almanca dilinin kullanımının sınırlı olması, öğrencilerin motivasyon eksikliği ve Almanca dersinin kredisinin düşük olması biçiminde sıralanmıştır. Öğrencilerin yabancı dili öğrenememesi görüşündeki öğretmenler ise bunu ana dili doğru kullanamamaya, yabancı dil öğrenme kaygısına sahip olmaya, Almancanın lise düzeyinde başlamasına ve yabancı dili içselleştirememeye bağlamışlardır. Bütün bu durumlara ilişkin doğrudan alıntı örnekleri aşağıda sunulmuştur: değiller...”

(Ö-31-k) “...öğrencilerimiz, dil öğrenmenin kendileri için yararının maalesef farkında bile

(Ö-1-e) “...Almancanın üniversite sınavda çıkmaması öğrenciler tarafından sorun olarak alg1lanıyor ve ilgiyi düşürüyor...."

(Ö-28-k) “...öğrenci tıpk1 İngilizce gibi Almancayı öğrenmeye de çok duyarsız; sınıfta farkl1 yöntem kullansam bile (drama etkinliği) öğrenciyi derse çekemiyorum..."

(Ö-1- e) “...dersin kredisinin az olması öğrencinin ilgisizliğine neden oluyor”

(Ö-23-e) “....aslında, öğrencilerimiz ana dilin kurallarına da tam hakim değiller ve etkili kullanamıorlar, bunun için yabancı dil öğrenme sürecinde de arzulanan başarıyı sağlayamiyorlar...."

(Ö-8-k) “...İngilizceyi zaten zor, Almancayı hiç yapamayız kaygısını taşıyor öğrenciler...”

(Ö-14-k) “...Almancayı ilk olarak lisede almaya başlıyor öğrenciler, bu durum da haliyle problemleri beraberinde getiriyor; bence çok daha erken yaşlarda, alt sınıflarda Almanca dersi olmal1...."

\section{Öğretmenlerin Almanca Öğretiminde Öğretmenden Kaynaklanan Sorunlara İlişkin Görüşleri}

Tablo 7'de öğretmenlerin Almanca öğretiminde öğretmenden kaynaklanan sorunlara ilişkin görüşlerine yer verilmiştir.

Tablo 7: Öğretmenden Kaynaklanan Sorunlara İlişkin Görüşler

\begin{tabular}{|c|c|c|}
\hline Temalar & Alt Temalar & $\mathrm{f}$ \\
\hline \multirow{5}{*}{ Alan/Mesleki yetersizlik } & Hizmet öncesi eğitimin yetersizliği & 12 \\
\hline & Kolay metotların tercih edilmesi & 3 \\
\hline & Konuşma becerisini etkin kullanamaması & 2 \\
\hline & Tek dil becerisi üzerinde yoğunlaşması & 2 \\
\hline & Hizmet içi eğitimin yetersizliği & 1 \\
\hline \multirow{4}{*}{$\begin{array}{l}\text { Öğretmenin } \\
\text { eksikliği }\end{array}$} & Rotasyondan kaynaklı tayin durumu & 2 \\
\hline & Öğrencinin ilgisizliği & 2 \\
\hline & Ders saatinin yetersiz olması & 1 \\
\hline & Dili öğretememe kaygısı & 1 \\
\hline
\end{tabular}

Araştırmada üzerinde durulan bir diğer konu, Almanca öğretiminde öğretmenden kaynaklanan sorunlardır. Öğretmenlerin görüşlerine bakıldığında bu sorunların; alan/meslek yetersizliği ve öğretmenin motivasyon eksikliği şeklinde iki kategoriye ayrıldığı görülmüştür. Alan/meslek yetersizliği için öğretmenler; hizmet öncesi eğitimin yetersizliği, kolay öğretim 
yöntemlerinin tercih edilmesi, öğretmenin konuşma becerisini etkin kullanamaması, öğretmenin tek dil becerisi üzerine yoğunlaşması ve hizmet içi eğitimin yetersizliği gibi durumları sıralamışlardır. Öğretmenin motivasyon eksikliği için ise katılımcılar; rotasyondan dolayı tayin durumuna, öğrencinin ilgisizliğine, ders saatinin yetersiz olmasına ve dili öğretememe kaygısına değinmiştir. Bütün bu durumlara ilişkin öğretmenlerin söylediklerinden alınan doğrudan alıntılar aşağıda verilmiştir:

(Ö-9-k) “...bence öğretmen yetiştirme programlarında eksiklikler var, teorik bilgiden çok uygulamalara önem verilmelidir..."

(Ö-3-e) “...öğretmenler daha çok dil bilgisi/çeviri metodunu kullanıyor; yeniliklere açık olmamiz gerekir..."

(Ö-1-e) “...sadece okuma-yazma becerisi üzerinde yoğunlaşmak problem, konuşmadinleme becerileri gelişmeyebiliyor..."

(Ö-16-k) “...öğretmenlerin rotasyondan dolayı sürekli yer değiştirmesi gerekiyor, bu nedenle öğretmenler sınıfa ve okula uyum sağlamada zorluk yaşayabiliyor, uyum problemleri olabiliyor ve derslere yansiyor....."

(Ö-18-k) “...derslerde öğrenciler isteksiz olunca öğretmenin de motivasyonu düşüyor....”

(Ö-8-k) "...ders saati yetersiz geliyor, aktarmak istediklerimi tam olarak aktaramiyorum...."

\section{Öğretmenlerin Almanca Öğretiminde Velilerin Bakış Açısından Kaynaklanan Sorunlara İlişkin Görüşleri}

Tablo 8'de öğretmenlerin Almanca öğretiminde velilerin bakış açısından kaynaklanan sorunlara ilişkin görüşlerine yer verilmiştir.

Tablo 8: Velilerin Bakış Açısından Kaynaklanan Sorunlara İlişkin Görüşler

\begin{tabular}{llc}
\hline Temalar & \multicolumn{1}{c}{ Alt Temalar } & $\mathrm{f}$ \\
\hline \multirow{2}{*}{$\begin{array}{l}\text { Almancayı yararl1/gerekli } \\
\text { görmeme }\end{array}$} & Mesleki gelişim için gerekli olmaması & 9 \\
\cline { 2 - 3 } & Sinav sisteminde soru sorulmaması & 8 \\
\cline { 2 - 3 } $\begin{array}{l}\text { Almancanın sadece not olarak } \\
\text { algılanması }\end{array}$ & Not ortalamasını yülanıseltmesi & 7 \\
\hline Ön yargılı olma & Zor bir dil olması & 5 \\
\hline
\end{tabular}

Almanca öğretiminde velilerin derse bakış açısından kaynaklanan problemler; Almancanın yararlı görülmemesi, sadece not ortalamasına etki ettiğinin ve zor olduğunun düşünülmesidir. Almancayı yararlı/gerekli görmeme teması içinde öğretmenler; velilerin Almancanın mesleki gelişim için gerekli olmadığını, üniversite giriş sınavında Almancaya yer verilmediğini ve Almancanın kullanım alanının olmadığını düşündüklerini belirtmiş̧lerdir. Bu konulara ilişkin örnek cümleler aşağıda sunulmuştur:

(Ö-31-k) “...veliler çocuklarının iş hayatında Almancaya ihtiyaç duyabileceklerinin bilincinde değiller, bu tabii ki öğrenciye de yansıyor..."

(Ö-30-k), “...veliler de öğrencilerimiz gibi hayatın sınavdan ibaret olduğunu sanıyorlar, Almancadan sınavda(üniversite sınavında) soru çıkmaması velileri etkiliyor açıkçası...."

(Ö-25-k) “...veliler çocuklarının (öğrencinin, Almanca dersini geçmesini ve sadece not ortalamalarını yükseltmelerini istiyor...." 
(Ö-4-e), “...Veliler de tıpkı öğrencilerimiz gibi bu dilin (Almancanın) zor bir dil olduğunu söylüyorlar, böyle düşünüyorlar bence..."

\section{Öğretmenlerin Almanca Öğretiminde Okulun}

\section{Fiziksel İmkânlarından Kaynaklanan Sorunlara İlişkin Görüşleri}

Tablo 9'da öğretmenlerin Almanca öğretiminde okulun fiziksel imkânlarından kaynaklanan sorunlara ilişkin görüşlerine yer verilmiştir.

Tablo 9: Okulun Fiziksel İmkânlarından Kaynaklanan Sorunlara İlişkin Görüşler

\begin{tabular}{llc}
\hline \multirow{2}{*}{ Temalar } & Alt Tema & $\mathrm{f}$ \\
\hline & İnteraktif öğrenmenin yapılamaması & 4 \\
\cline { 2 - 3 } & Dersin dinamiğinin azalması & 4 \\
\cline { 2 - 3 } Araç-gereçlerin yeterli olmaması & Dile ilginin azalması & 3 \\
\cline { 2 - 3 } & Aktivitelerin kısıtlı yapılması & 12 \\
\hline \multirow{2}{*}{ Dil laboratuvarının olmaması } & & 10 \\
\hline \multirow{2}{*}{ Her okulun eşit imkânlara sahip olmaması }
\end{tabular}

Öğretmenlerin görüşlerine göre Almanca öğretiminde okulun fiziksel imkânlarından kaynaklanan sorunlar, araç-gereçlerin yeterli olmaması, dil laboratuvarının olmaması ve her okulun eşit imkânlara sahip olmamasıdır. Araç-gereçlerin yeterli olmadığını belirten öğretmenler bunun sonucu olarak; interaktif öğrenmenin yapılamaması, dersin dinamiğinin azalması, dile ilginin azalması ve aktivitelerin kısıtlı yapılmasına dikkat çekmişlerdir. Örnek alıntılar şöyle siralanmaktadır:

(Ö-9-k) “...bence interaktif öğrenmeye uygun öğretim materyallerimizin olmaması dil öğretiminde büyük problem ..." veriyor...."

(Ö-12-k) “...gerekli donanım ve ekipmanlarımızın bulunmaması dersin dinamikliğine zarar

(Ö-25-k) “...resmi okullardaki teknolojik araç-gereç yetersizliği, mecburen dersiçi etkinliklerin çeşitliliğini, sayısını olumsuz etkiliyor...."

(Ö-17-k) “....düşünsenize, müzik dersi için ayrı müzik sınıfı, beden eğitimi dersi için kocaman spor salonu var; yabancı dil eğitimi için de laboratuvar olmalı...."

(Ö-26-k) “...özel okulların devlet okullarına göre imkânlarının daha iyi olması öğrencilerin yabancı dil seviyelerinde belirgin farka neden oluyor..."

\section{Almanca Öğretmenlerinin İkinci Yabancı Dil Olarak Almanca Öğretiminin Etkili Olabilmesi İçin Önerileri}

Tablo 10'da Almanca öğretmenlerinin ikinci yabancı dil olarak Almanca öğretiminin daha iyi ve daha etkili olabilmesi amacıyla sıraladıkları önerilere yer verilmiştir. 
Tablo 10: İkinci Yabancı Dil Olarak Almanca Öğretiminin Etkili

Olabilmesi İçin Öneriler

\begin{tabular}{|c|c|c|}
\hline Temalar & Alt Temalar & $\mathrm{f}$ \\
\hline \multirow{6}{*}{$\begin{array}{l}\text { Resmi boyutta } \\
\text { yapılması gerekenlere } \\
\text { ilişkin öneriler }\end{array}$} & Üniversiteye giriş sınavında soru sorulması & 5 \\
\hline & Öğretim programının yeniden düzenlenmesi & 4 \\
\hline & Ders saatlerinin arttırılması & 4 \\
\hline & Liselerde öğrenci değişim programlarının olması & 3 \\
\hline & Öğretmen istihdamının arttırılması & 2 \\
\hline & $\begin{array}{l}\text { Ders içi etkinliklerde konuşma ve dinleme } \\
\text { becerisinin öncelenmesi }\end{array}$ & 1 \\
\hline \multirow{3}{*}{$\begin{array}{l}\text { Öğretmen ve diğer } \\
\text { paydaşlara ilişkin } \\
\text { öneriler }\end{array}$} & $\begin{array}{l}\text { Öğretmen, öğrenci, veli ve idari kadronun yabancı } \\
\text { dil öğretimi konusunda bilinçlendirilmesi }\end{array}$ & 9 \\
\hline & $\begin{array}{l}\text { Öğretmenlerin hizmet öncesi eğitiminin gözden } \\
\text { geçirilmesi }\end{array}$ & 5 \\
\hline & Öğretmenlerin olumlu tutum geliştirmeleri & 1 \\
\hline \multirow{5}{*}{$\begin{array}{l}\text { Kaynak ve materyale } \\
\text { ilişkin öneriler }\end{array}$} & Yabancı dil kütüphanesi oluşturulması & 2 \\
\hline & Materyal ve kaynakların kültüre uyarlanmış olması & 1 \\
\hline & Materyal ve kaynakların arttırılması & 1 \\
\hline & Materyal ve kaynak içeriklerinin gözden geçirilmesi & 1 \\
\hline & Öğrenci ve derslik sayılarının orantılı olması & 1 \\
\hline \multirow{2}{*}{$\begin{array}{l}\text { Motivasyon/istek } \\
\text { boyutundaki öneriler }\end{array}$} & Öğrencinin motivasyonu yükseltme & 4 \\
\hline & Almancanın isteğe bağlı öğretilmesi & 2 \\
\hline Dilin kullanım alanına & kin öneriler & 5 \\
\hline
\end{tabular}

Öğretmenlerin önerileri, resmi boyutta yapılması gerekenlere ilişkin, öğretmen ve diğer paydaşlara ilişkin, materyale ilişkin, motivasyon/istek boyutuna ilişkin ve dilin kullanım alanına ilişkin öneriler şeklinde sıralanmaktadır. Resmi boyutta yapılması gerekenlere ilişkin öneriler; üniversiteye giriş sınavında soru sorulması, öğretim programının yeniden düzenlenmesi, ders saatlerinin arttırılması, liselerde öğrenci değişim programlarının olması, öğretmen istihdamının arttırılması ve ders içi etkinliklerde konuşma ve dinleme becerisinin öncelenmesi şeklinde sıralanmıștır. Öğretmen ve diğer paydaşlara ilișkin öneriler, öğretmen, öğrenci, veli ve idari kadronun yabanc1 dil öğretimi konusunda bilinçlendirilmesi, öğretmenlerin hizmet öncesi eğitiminin gözden geçirilmesi ve öğretmenlerin olumlu tutum geliştirmeleri olarak belirlenmiştir. Kaynak ve materyale ilişkin öneriler, yabancı dil kütüphanesi oluşturulması, okulların araç-gereç donanımlarının arttırılması, materyal ve kaynakların kültüre uyarlanmış olması, materyal ve kaynakların arttırılması, materyal ve kaynak içeriklerinin gözden geçirilmesi ve öğrenci-derslik sayılarının orantılı olması biçiminde sıralanmıştır. Motivasyon/istek boyutundaki öneriler, öğrenci motivasyonunu yükseltme ve Almancanın isteğe bağlı öğretilmesi olarak belirlenmiştir. Dilin kullanım alanına ilişkin önerilerde ise Almancanın kullanım alanının artırılması yer almaktadır. Bu önerilere ilişkin doğrudan alıntı cümleleri aşağıda sıralanmıştır: çözülecektir...."

(Ö-23-e) “...üniversite giriş sınavında Almancaya yerverilse pek çok problem 
(Ö-14-k) “....daha etkili Almanca öğretimi için bence ders saatlerinde artış olmalı ...”

(Ö-16-k) “...lise öğrencilerinin uluslararası değişim programlarına katılmaları sağlanabilir, bu Almancaya ilgiyi arttırabilir ve daha etkili öğrenme oluşabilir..."

(Ö-15-e) “...uygun ortam sağlanırsa konuşma ve dinleme becerilerinin daha etkili olması mümkün olabilir...”

(Ö-7-e), “...öğrencilerin kaynaklara hemen ulaşmalarını sağlayacak biçimde yabancı dil kütüphaneleri oluşturulabilir..."

(Ö-8-k) “... teknolojik araç-gereçlerin sayısı ve kullanımı arttırılarak dört temel beceri üzerine yoğunlaşılabilir...."

(Ö-13-e) “... hedef dilin (Almancanın) kültürünü yansıtması öğretim materyalleri kullanılabilir ve materyallerin uyarlanmış olması gerekir..."

(Ö-32-e) “...Bu ders zorunlu olmamalı bence, isteğe bağlı olursa daha yararlı olabilir...”

\section{Sonuç ve Tartıșma}

Değişen dünyayla birlikte yabancı dile olan gereksinim her geçen gün büyümektedir. $\mathrm{Bu}$ bağlamda bireylerin yabancı dil yeterliklerinin artması beklenirken, bir değil birkaç yabancı dilin kullanılması zaruri hale gelmiştir. Yabancı dile gramer kuralları bakımından hâkim olunsa bile özellikle konuşma becerisinin kullanılması noktasında sorunlar olduğu kabul edilmektedir. $\mathrm{Bu}$ araştırmada yabancı dil olarak Almanca üzerinde çalışma yürütülmüştür. Okullarda yabancı dil olarak İngilizcenin gölgesinde kaldığı düşünülen Almancanın öğretiminde birtakım sıkıntılar yaşandığı düşünülmektedir. $\mathrm{Bu}$ durumun öğretmenlerin bakış açısıyla değerlendirilmesi hedeflenmiştir.

Araştırma kapsamında öğretmenlerin ikinci yabancı dil olarak Almancayı gerekli gördükleri ve İngilizceden sonra ikinci önemli dil olmasını vurguladıkları görülmüştür. Benzer sonuç, Can ve Can'ın (2014) çalışmasında da ortaya konmuştur. Bir başka çalışmada da İngilizceden sonra Almancanın ikinci önemli yabancı dil olduğu; İngilizce ve Almancanın aynı dil grubundan geldiği; İngilizcede edinilen bilgilerin olumlu transferle Almanca öğretimini kolaylaştırdığı ortaya konmuştur (Genç, 2003). Yine benzer bir çalışmada ikinci yabancı dil öğrenirken, birinci yabanc1 dilden edinilen bilgi ve deneyim ile öğrenmenin daha kolay olacağını vurgulanmıştır (Arak, 2016). İngilizceden sonra ikinci yabancı dil olarak kabul gören Almancanın verilmesinin dezavantajdan çok avantaj sağladığı belirtilmektedir (Wypusz, 2015). Mevcut araştırmada, Almanca öğretiminde öğretmenlerin vurguladığı ve öğrenciden kaynaklanan sorunlara bakıldığında, öğrencilerin bahsi geçen olumlu transferi gerçekleştiremedikleri düşünülebilir. Öğrencilerin Almancayı öğrenmede sorun yaşadıkları; bunun sonucu olarak da dili öğrenememe kaygısı, ana dile tam hâkim olamamaları ve yabancı dili içselleştirememeleri gibi durumlar ortaya çıkmıştır. Araştırmada, öğretmenlerin ikinci yabancı dili gerekli gördüklerine ilişkin olarak, dil kültür boyutunda dünya ülkeleri ile kültürel iletişim ve diyalog kurma durumuna vurgu yapıldığı görülmüştür. Yabancı dil öğretiminin kültür aktarımı olarak tanımlanabileceğine, öğrenenin hedef dili öğrenirken o kültürü de tanımasının dili daha iyi öğrenmeye katkı sağlayacağına; ayrıca, hedef dilin kültürünü tanıyarak o dili öğrenmenin, o kültürdeki insanların olaylara karşı verdikleri tepkileri anlamak için de yardımcı olacağına ilişkin görüşler bulunmaktadır (Alpar, 2013).

Araştırma kapsamındaki öğretmenlerin ikinci yabancı dil olarak Almancayı, kariyer planlama ve değişen dünyaya uyum noktasında gerekli gördükleri; ancak öğretim sürecinde yaşanan sorunlu durumların bulduğu ortaya konmuştur. Öğretim yöntem ve tekniklerinden kaynaklı bazı problemlerin olduğu; öğretim kaynak/materyallerinin, ders saatlerinin yetersiz oluşu ve öğretmenlerin geleneksel yöntem-tekniklerden çok fazla uzaklaşamamadıkları çalışma kapsamında 
ortaya konmuştur. Benzer bir çalışmada Almancayla öğretimiyle ilgili kaynak sıkıntısı yaşandığı belirtilmektedir (Balc1, 2016).

Yöntem-tekniklerden kaynaklanan sorunlar arasında öğretmenlerin alışılmışın dışına çıkamaması yer almaktadır. Dilbilgisi-çeviri metodunun kullanılması, konuşma becerisinin öncelikli olmaması ve geleneksel yöntem ve tekniklerin tercih edilmesi gibi sorunlar dikkat çekmektedir. Koçak ve Çobanoğulları (2017) benzer duruma vurgu yaparak, Türkiyede Almanca öğretmenlerinin derslerde konuşma becerilerini ihmal ettikleri ve dil bilgisi öğretimine daha fazla ağırlık verdiklerini ortaya koymuşlardır. Giebert (2014)'e göre öğrencilere yabancı dil öğretirken geleneksel metotların dışına çıkılarak drama, rol yapma, eğitsel oyunlar gibi tekniklerin kullanılması gerekmektedir; çünkü geleneksel uygulamaların dışına çıkılarak yapılan etkinliklerin yabancı dil öğretiminde kalıcıllı̆ın daha yüksek olmasını sağlayacağı vurgulanmıştır. Benzer biçimde Kırmızı (2012) da farklı tekniklerle dersi yürütmenin, öğrenciler açısından daha olumlu durumlar ortaya çıkaracağını belirtmiştir. Mevcut araştırmada öğretim yaparken daha çok dilbilgisi-çeviri metodunun kullanılması ve konuşma becerisinin öncelikli olmaması öğretmenlerin karşılaştıkları diğer sorunlardır. Şevik (2008) Avrupa ülkelerinin birçoğunda yabancı dil öğretiminde konuşma ve dinleme becerisinin geliştirilmesine daha çok önem verildiğini vurgulamıştır. Avrupa ülkeleri bu becerilerin gelişmesi için yabancı dil öğretim programlarını bu becerileri önceleyerek düzenlemiştir.

Araştırmada üzerinde durulan bir diğer sorunlu durum, ölçme-değerlendirmedir. Özellikle dört temel dil becerisine yönelik olmayan ölçme değerlendirme ve daha çok yazılı sınavın tercih edilmesi en temel problemlerdir. Yapılan farklı bir çalışmada da benzer sonuçlara ulaşılmıştır; ezbere dayalı klasik ölçme-değerlendirmenin ikinci yabancı dil öğretimini olumsuz etkilediği vurgulanmıştır (Can ve Can, 2014). Bir diğer çalışmada da, yabancı dil öğretiminde ölçmedeğerlendirme yapılırken, yazılı sınavdan ziyade her öğrencinin bireysel dil gelişimlerini gösteren değerlendirmeler yapılabileceği, böylece dili öğrenirken zayıf yönlerin belirlenip bunların giderilebileceği ortaya konmuştur (Bozavl1, 2014). Haznedar (2010) da, yabancı dil öğretmenlerinin \%89'unun ölçme değerlendirmede yazılı sınav uyguladığını belirtirken, yabancı dil öğretiminde ölçme değerlendirme aracı olarak yazılı sınavın, bu kadar yüksek düzeyde kullanılmasının sorgulanması gereken bir durum olduğunu belirtmiştir. Bunun yanında araştırma kapsamındaki öğretmenler, öğrenci motivasyonunun ölçme-değerlendirmeden olumsuz etkilenmesi ve öğretmenlerin bu konuda yeterince donanımlı olmayışlarını da bir diğer problem olarak ortaya koymuşlardır.

Öğretmenlerin, Almanca öğretiminde yürütülen ders içi etkinliklere yönelik sorunlu durumların hem öğretmenden hem de öğrenciden kaynaklı olduğunu vurguladıkları ve dört temel dil becerisine yönelik etkinlik yapılmamasının ön plana çıktığı görülmüştür. Oysaki Ege (2011), yaptığ1 çalışmada dilin üretim boyutu olan yazma becerisinin önemi üzerinde durarak, öğretim sürecinde yazma becerisine ilişkin etkinliklerin öğrencilerin dili daha iyi kullanmalarını sağlayan bir durum olduğunu vurgulamıştır. Kırmızı (2009)'nın yürüttüğü çalışmanın sonuçları mevcut araştırmanın sonucuyla örtüşmektedir; ders saatinin yetersizliği nedeniyle okuma, yazma ve konuşma becerilerine yönelik yeterince etkinlik yapılmadığı belirlenmiştir. Bu durum Çolakoğlu-Saburlu'nun (2019) yapmış olduğu çalışmanın sonuçlarıyla benzeşmektedir; ders sürelerinin yetersizliğinden dolayı öğretmenlerin yeterli etkinlik yapamadığına vurgu yapılmıştır. Mevcut çalışmada ise, ders içi etkinliklere yönelik öğrenci boyutunda yaşanan sorunlar, motivasyon eksikliği ve etkinliklerin öğrenciler tarafindan anlaşılamamasıdır.

Araştırmada bir diğer üzerinde durulan konu, Almanca öğretmenlerinin Almanca öğretiminde öğrenciden kaynaklanan sorunlara ilişkin görüşleridir. Bu bağlamda, öğrencilerin ilgisizliği, yabancı dili öğrenememeleri ve yabancı dilin önemini kavrayamamaları biçiminde sonuçlara ulaşılmıştır. Öğrencinin ilgisiz ve isteksiz oluşu, üniversite sınavında Almancadan soru sorulmaması başta olmak üzere Almancanın kullanımının sınırlı olması, öğrencilerin motivasyon 
eksikliği ve Almanca dersinin kredisinin düşük olması gibi durumlara bağlanmıştır. İkinci yabanc1 dil öğretiminde karşılaşılan sorunların incelendiği başka bir çalışmada, üniversite sınavında Almancadan soru sorulmamasının öğrencilerin bu dersi önemsememelerine gerekçe olduğu vurgulanmıştır (Can ve Can, 2014). Mevcut araştırmada öğrencilerin yabancı dili öğrenememe sebeplerinden biri ana dili yeterince kullanamamaya bağlanmıştır. Bu durum Yılmaz (2007) tarafindan da vurgulanırken, anadilin kendisinden sonra gelen tüm dilleri etkilediği, anadile hâkimiyetin, diğer dilleri daha kolay ve hızlı öğrenmeye yardımcı olduğu ifade edilmiştir.

Öğrenciden kaynaklanan sorunlara ilişkin konulardan biri de öğrencinin ilgi ve isteksizliğine bağlı olarak yabancı dili öğrenmeye karşı öğrencide oluşan motivasyon eksikliğidir. Marım (2013), öğrencinin motivasyonun yükseltilmesi için derste işlenecek olan konuların güncel ve ilgi çekici olması gerektiğini belirtmiştir. Ayrıca söz konusu çalışmada ders işlenirken somut alıştırmaların yapılması, öğrencinin motivasyonunu yükselteceğine dikkat çekilmiştir. İkinci yabancı dil ediniminde motivasyonun önemine dikkat çekilen bir araştırmada ikinci yabanc1 dil öğretim sürecinde motivasyon eksikliği olmasının öğrenme sürecini zorlaştıracağını vurgulamıştır (Porsteinsdóttir, 2014). Öğrenciden kaynaklanan sorunlara ilişkin diğer bir konu ise Almancanın lise düzeyinde başlaması ve bu nedenle öğrencilerin öğrenmede güçlük çekmesidir. Nitekim farklı bir araştırmada ikinci yabancı dil öğretiminin daha alt eğitim kademelerinde başlanmasının daha olumlu sonuçlar verebileceğine vurgu yapılmıştır (Šenderová, 2016). Koçak ve Çobaoğulları (2017) da benzer durumu vurgulayarak; okullarda ikinci yabancı dile daha erken yaşlarda başlanmasının sorunlara çözüm olmada bir yol olabileceğini belirtmişlerdir. Almanca öğretmenleri, öğrencilerin yabancı dilin önemini kavrayamamasını diğer bir sorunlu durum olarak belirtmişlerdir. Nitekim Koçak ve Çobanoğulları'nın (2017), Türkiye'deki ve Danimarka'daki öğrencilerin görüşlerini değerlendirdikleri çalışmalarında ikinci yabancı dil olarak Almanca öğretiminde Danimarka'daki öğrencilerin öğretilen yabancı dili hedeflerine ulaşmayı kolaylaştırıcı bir araç olarak gördüklerini; anacak Türkiye'deki öğrencilerin öğretilen yabancı dili önemsiz bulduklarını tespit etmişlerdir.

Almanca öğretmenlerinin Almanca öğretiminde öğretmenden kaynaklanan sorunlara ilişkin olarak mesleki yetersizlik boyutunda, hizmet öncesi eğitimin yetersizliği ve öğretmenin dili etkin kullanamaması en çok vurgulanan görüşler olmuştur. AB ülkelerinde yabancı dil dersi öğretmenlerinin başka bir yabancı dil dersini öğretebilecek nitelikte oldukları; ancak Türkiye öğretmenlerin böyle bir yeterliğe sahip olmadıkları ifade edilmektedir (Tok ve Arıbaş, 2008). Mevcut çalışmada öğretmenler tarafından sorun olarak yabancı dil öğretmenlerinin hizmet öncesi eğitimlerinin yetersiz olmasına vurgu yapılmıştır. Yabancı dil öğretmen adayları üzerinde yapılan bir araştırmada, mesleğine yönelik yeterliliğe sahip olmanın gerekli olduğu; bu yeterliliğin de hizmet öncesi eğitimde alınması gerektiği belirtilmiştir (Uygur ve Çakır, 2015).

Öğretmenlerin kendilerinden kaynaklanan sorunlara ilişkin olarak motivasyon eksikliği boyutundaki görüşleri incelendiğinde, rotasyondan kaynaklı tayin durumu, öğrencinin ilgisizliği, ders saatinin yetersiz olması ve dili öğretmeyeceği kaygısı gibi durumlara ulaşılmıştır. Dil öğretmeye ilişkin kaygı duyma vurgusu farklı çalışmalarda da mevcuttur (Barnes ve Lock, 2013). Söz konusu çalışmada, öğretmenlerin dili öğretirken yanlış cümle kurma ve anlaşılamamaktan çekindikleri ortaya konmuştur. Bunun sonucunda ise öğrencinin öğretmene bakış açısının değiştiği, öğretmenin de kaygı ve motivasyon sorunu yaşayabileceği ortaya konmuştur. Yine Koçak ve Çobanoğulları (2017) da öğrencilerin Almancaya ilgi duymamaları ve isteksizliklerinin öğretmen ve müfredatın öğrenme üzerindeki olumlu etkisini azaltacağını belirtmiştir.

Öğretmenlerin velilerin bakış açısından kaynaklanan sorunlara ilişkin görüşleri incelendiğinde, velilerin Almancayı yararlı/gerekli görmedikleri, sadece not alınacak bir ders olarak görmeleri, dersi zor bulmaları, üniversite giriş sınavında Almancaya yer verilmediği ve Almancanın kullanım alanının olmadığını düşündüklerini belirtmişlerdir. Benzer biçimde Can ve Can'ın (2014) çalışmalarında da ikinci yabancı dil öğretiminde ailelerin bilgi eksikliklerinin olması, üniversite 
sınavında soru çıkan derslerin daha fazla önemsenmesi gerektiği gibi durumlar ailelerden kaynaklı sorunlar olarak ifade edilmiştir. Yapılan bir çalışmada araştırma sonuçlarıyla farklılaşan sonuçlara ulaşılmıştır. Söz konusu çalışmada velilerin yabancı dil öğretimini destekledikleri, yabancı dil öğretiminin daha erken yaşta başlaması gerektiğine vurgu yaptıkları görülmüştür (Genç-İlter ve Er, 2007). Üzerinde durulan bir diğer konu, okulun fiziksel imkânlarına dönüktür. Bunlar araç-gereçlerin yeterli olmaması, dil laboratuvarının olmaması ve her okulun eşit imkânlara sahip olmaması şeklindedir. Batman ilinde yürütülen bir çalışmada, Anadolu Liselerinin hepsinde yabancı dil dersi verilmesine rağmen; bu okullarda dil laboratuvarı ya da dil sınıfının olmadığı vurgulanmıştır (Balcı, 2016).

Öğretmenlerin Almanca öğretiminin daha etkili olabilmesi için bir takım önerileri bulunmaktadır. Resmi boyutta yapılması gerekenler, öğretmen ve diğer paydaşlara ilişkin öneriler, kaynak ve materyale ilişkin öneriler, motivasyon/istek boyutundaki öneriler ve dilin kullanım alanına ilişkin öneriler sıralanmıştır. Öğretmenlerin, öğretmen ve diğer paydaşlara ilişkin önerileri incelendiğinde öğretmen, öğrenci, veli ve idari kadronun yabancı dil öğretimi konusunda bilinçlendirilmesi, öğretmenlerin hizmet öncesi eğitimin gözden geçirilmesi, öğretim programlarının düzenlenmesi ve öğretmenlerin olumlu tutum geliştirmelerine dikkat çektikleri görülmektedir. Benzer biçimde Koçak ve Çobanoğulları (2017) da ikinci yabancı dil olarak Almanca öğretiminde güncel yöntem ve öğretim materyali kullanımına dikkat çekmiştir. Yapılan bir araştırmada Türkiye'de, yabancı dil öğretmenlerinin hizmet öncesi eğitimlerinde kalite standartlarının olması gerektiği; bununla birlikte okul yöneticilerinin ve denetmenlerin yabancı dil öğretimiyle ilgili daha donanımlı hale gelmeleri gerektiği belirtilmiştir (Coşkun-Demirpolat, 2005). Mevcut çalışmada öğretmenlerin daha etkili bir Almanca öğretimi için, öğretmen ve diğer paydaşlara ilişkin öneriler incelendiğinde, öğretmenlerin olumlu tutum geliştirmelerine yönelik önerilere de rastlanılmıştır. Yapılan bir çalışmada yabancı dil öğretimi yapacak öğretmenlerin taşıması gerekn özellikler arasında öğrenciyle güzel diyalog kurabilme, öğrencilerin güvenini arttırma, eğlenceli bir sınıf atmosferi yaratma gibi durumlara dikkat çekilmiştir (Zamani ve Ahangari, 2016). Bunun yanında mevcut araştırmada öğretmenlerin öğretim programlarında düzenlemelerin yapılmasına vurgu yaptıkları görülmüştür. Benzer biçimde Yılmaz (2007) da Almanca programının birinci yabancı dil İngilizce programından yararlanılarak gözden geçirilebileceğini; böylece diğer yabancı dil öğrenilirken edinilen deneyim ve bireyin geliştirdiği stratejilerden olumlu biçimde yararlanılabileceğini vurgulamıştır.

\section{Öneriler}

Araştırma sonuçlarına bağlı olarak aşağıdaki öneriler sunulmuştur:

- Yabancı dil öğrenmenin ve ikinci yabancı dil ediniminin önemi öğrenciye anlatılmalıdır. Almanca not alma ve sınıf geçme kaygısı yaşamadan öğrenciye aktarılmalıdır.

- Yabancı dil dersleri için dil kütüphaneleri oluşturulmalıdır. Bu kütüphanelerde kitaplarla birlikte görsel ve işitsel materyaller öğrencilerin kullanımına sunulmalıdır. Böylece öğrencinin yabancı dile olan ilgisi ve motivasyonu arttırılmalıdır.

- Daha verimli bir Almanca öğretimi için okulların imkânları gözden geçirilmeli ve iyileştirilmelidir.

- Almanca dersinin saatleri, dört temel dil becerisinin daha aktif ve işlevsel kullanılabilmesi için gözden geçirilmeli ve yeniden planlanmalıdır.

- İkinci yabancı dil eğitimi idaha küçük yaş düzeyinde verilmelidir; böylece ikinci yabancı dil derslerinin lise düzeyinde verilmesinden kaynaklanan sorunların önüne geçilmesi sağlanmalıdır. 


\section{Kaynakça}

Ada, S. ve Şahenk, S. S. (2010). Avrupa dil portfolyosu ve Türkiye'de yabancı dil eğitimi, Avrupa Araştırmaları Dergisi, 18 (1-2), 63-88. https://doi.org/10.31464/jlere.592835

Akıllılar, T. (2013). İkinci yabancı dil olarak Almanca öğreniminde üstbilişsel farkındalık, Uşak Üniversitesi Sosyal Bilimler Dergisi. Özel Say1, 275-285. https://doi.org/10.12780/uusbd187

Aksan, D. (1999). Her yönüyle dil ana çizgileriyle dilbilim. Ankara: Türk Dil Kurumu Yayınları.

Alpar, M. (2013). Yabancı dil öğretiminde kültürel unsurların önemi. The Journal of Language and Linguistic Studies, 9(1): 95-106.

Arak, H. (2016). İngilizceden sonra ikinci yabanc1 dil olarak almanca. The Journal of Academic Social Science Studies, (48): 15-25. https://doi.org/10.9761/jasss3491

Balcı, U. (2016). Anadolu liselerinde ikinci yabancı dil olarak Almanca eğitimi: Batman ili örneği. Dicle Üniversitesi Ziya Gökalp Eğitim Fakültesi Dergisi, (29): 346-355. https://doi.org/10.14582/duzgef.757

Barnes, B. D. ve Lock, G. (2013). Student perceptions of effective foreign language teachers: a quantitative investigation from a korean university. Australian Journal of Teacher Education, 38 (2): 19-36. https://doi.org/10.14221/ajte.2013v38n2.2

Bozavlı, E. (2013). Yabancı dil öğretiminde alternatif bir okul modeli. Akademik Sosyal Araştırmalar Dergisi, 2(1): 110-120. https://doi.org/10.16992/asos.75

Bür, B. ve Aycan, A. (2013). Birinci yabancı dil olarak öğrenilen ingilizcenin ikinci yabancı dil Fransızcanın öğrenim sürecine etkisi, Turkish Studies - International Periodical For The Languages, Literature and History of Turkish or Turkic, 8/10, 193-207. https://doi.org/10.7827/turkishstudies.5914

Can, E. ve Can, C, I. (2014). Türkiye'de ikinci yabancı dil öğretiminde karşılaşılan sorunlar. Trakya Üniversitesi Eğitim Fakültesi Dergisi, 4(2): 43-63. https://doi.org/10.19171/uuefd.29695

Chomsky, N. (2009). Bilgi sorunlarl ve dil managua dersleri. (Çev. V. Kılıç.) İstanbul: Bgst Yayınları.

Coşkun-Demirpolat, B. (2015). Türkiye'nin yabancı dil öğretimiyle imtihanı: sorunlar ve çözüm önerileri. Analiz, SETA, (131): 1-19. http://file.setav.org/Files/Pdf/20150707131308_131_yabancidil_web.pdf adresinden 21 Temmuz 2019 tarihinde erişilmiştir

Çelikkaya, Ş. (2013). Ortaöğretim öğrencilerinin ikinci yabancı dil almanca dersine yönelik tutumlar1. Middle Eastern\&African Journal of Educational Research, (5): 96-109.

Çolakoğlu-Saburlu, Z. (2019). Students' perceptions towards the use of first language in the foreign language classroom. European Journal of Foreign Language Teaching, 4 (2): 44-61.

Ege, İ. (2011). İkinci yabancı dil (Almanca) ögretiminde Avrupa dil portfolyosuna dayalı uygulamaların etkililiğinin değerlendirilmesi, Yayımlanmamış doktora tezi, Selçuk Üniversitesi, Eğitim Bilimleri Enstitüsü, Konya. https://doi.org/10.1501/egifak_0000000796

Genç, A. (2003). İlk ve ortaöğretim kurumlarında Almanca programları. Hacettepe Üniversitesi Ĕ̈itim Fakültesi Dergisi, (24): 186-195.

Genç-İlter, B. ve Er, S. (2007). Erken yaşta yabancı dil öğretimi üzerine veli ve öğretmen görüşleri. Kastamonu Eğitim Dergisi, 15(1): 21-30. https://doi.org/10.17679/inuefd.644728 
Giebert, S. (2014). Drama and theatre in teaching foreign languages for professionals purposes. Langues de spécialité et professionnalisation, XXXIII (1): 138-150. https://doi.org/10.4000/apliut.4215

Gurbetoğlu, A. (2008). Bilimsel araştırma yöntemleri. (http://agurbetoglu.com/files/2\%20ARA\%C5\%9ETIRMA\%20\%20T\%C3\%9CRLER\%C4 \%B0.pdf; 21 Temmuz 2019 tarihinde edinilmiştir). https://doi.org/10.26899/inciss.182

Gündoğdu, M. (2005). Avrupa birliği yolunda Türkiye'nin yabancidil politikası, Çukurova Üniversitesi Eğitim Fakültesi Dergisi, 29 (2), 120-127.

Güzel, A. (2014). İki dilli türk çocuklarına Türkçe öğretimi: Almanya örneği (3.baskı). Ankara: Akçağ Yayınları. https://doi.org/10.17860/mersinefd.282398

Haznedar, B. (2010, Nov). Türkiye' de yabancı dil eğitimi: reformlar, yönelimler ve öğretmenlerimiz. International Conference on New Trends in Education and Their Implications, Antalya/TURKEY.(http://webcache.googleusercontent.com/search?q=cache:http://www.ic onte.org/FileUpload/ks59689/File/166.pdf; adresinden 21 Temmuz 2019 tarihinde edinilmiştir.).

Hengirmen, M. (2009). Dilbilgisi ve dilbilim terimleri sözlüğü (3. bask1). Ankara: Engin Yayınevi.

Karaman, F. (2017). Temel eğitimde ikinci yabancı dil olarak almanca öğretimi. Batman Üniversitesi Yaşam Bilimleri Dergisi, 7 (2): 104-110. https://doi.org/10.14582/duzgef.757

Karasar, N. (2016). Bilimsel araştırma yöntemi. (30.baskı). Ankara: Nobel Akademik Yayıncılık.

Karataş, Z. (2015, Ocak). Sosyal bilimlerde nitel araştırma yöntemleri. Manevi Temelli Sosyal Hizmet Araştırmaları Dergisi, 1(1): 62-80. https://doi.org/10.21560/spcd.vi.460937

Kırmızı, B. (2012). Almanca derslerinde altı şapkalı drama tekniğinin öğrencilerin başarısına etkisi. Adlyaman Üniversitesi Sosyal Bilimler Enstitüsü Dergisi, 5(10): 265-290. https://doi.org/10.14520/adyusbd.338

Koçak, M. ve Çobanoğulları, F. (2017). Dünyada ikinci yabancı dil olarak Almanca öğretiminde Danimarka örneği. Uluslararası Ĕ̈itim Bilimleri Dergisi, 1(1): 1-12. https://doi.org/10.14582/duzgef.757

Marım, E. (2013). İkinci yabancı dil Almancanın ögrretiminde yabancı dil ögretim kuramlarının uygulanabilirliği. Yayımlanmamış doktora tezi, Ankara Üniversitesi Sosyal Bilimler Enstitüsü, Ankara. https://doi.org/10.1501/egifak_0000000796

MEB (2006a). Yabanc1 dil eğitimi ve öğretimi yönetmeliği, http://mevzuat.meb.gov.tr/dosyalar/424.pdf adresinden 20 Temmuz 2019 tarihinde edinilmiştir. https://doi.org/10.31589/joshas.189

MEB (2006b). Ortaöğretim kurumları 10, 11 ve 12. sınıf ikinci yabancı dil olarak Almanca dersi öğretim programı. https://docplayer.biz.tr/3263049-Ortaogretim-kurumlari-10-11-ve-12sinif-ikinci-yabanci-dil-almanca-dersi-ogretim-programi.html adresinden 20 Temmuz 2019 tarihinde edinilmiştir.

MEB (2010). Genel liselerin anadolu liselerine dönüştürülmesi. Genelge/2010/30, http://mevzuat.meb.gov.tr/dosyalar/934.pdf adresinden 1 Temmuz 2019 tarihinde edinilmiştir.

MEB (2012). 12 y1l zorunlu eğitim sorular-cevaplar, 24-25. http://www.meb.gov.tr/duyurular/duyurular2012/12yil_soru_cevaplar.pdf adresinden 2 temmuz 2019 tarihinde edininlmiştir. 
MEB (2013). Diller için avrupa ortak öneriler çerçevesi: öğrenim, öğretim ve değerlendirme, telc $\mathrm{GmbH}$ Frankfurt/Main, Almanya. https://www.telc.net/fileadmin/user_upload/Publikationen/Diller_iain_Avrupa_Ortak_oneri ler_AEeraevesi.pdf adresinden 20 Temmuz 2019 tarhinde edinilmiştir. https://doi.org/10.14527/9786052415375.03

MEB, (2018). Ortaöğretim kurumları haftalık ders çizelgesi, Talim Terbiye Kurulu, http://ttkb.meb.gov.tr/meb_iys_dosyalar/2018_02/21173451_ort_ogrtm_hdc_2018.pdf adresinden 10 Temmuz 2019 da edinilmiştir.

Miles, M. B. ve Hubermann, A. M. (1994). Qualitative data analysis: a expanded sourcebook (2nd ed). Thousand Oaks: CA.

Resmi Gazete, (7 Eylül 2013). Millî eğitim bakanlığı ortaöğretim kurumları yönetmeliği, 28758, https://www.resmigazete.gov.tr/eskiler/2013/09/20130907-4.htm adresinden 17 Temmuz 2019 tarihinde edinilmiştir.

Šenderová, B. L. (2016). Deutsch als drittsprache. welchen einfluss hat die fremdsprache Englisch auf Deutsch ernende tschechen und tschechinnen?. Yayımlanmamış doktora tezi, Plzeň, Česká Republika: Učitelství pro SŠ, obor Nj-Aj.

Şevik, M. (2008). Avrupa ülkelerinde ilköğretim birinci kademe zorunlu yabancı dil öğretiminin karșılaştırılması. Ankara Üniversitesi Eğitim Bilimleri Enstitüsü Dergisi, 41(1): 135-162. https://doi.org/10.1501/egifak_0000000188

Porsteinsdóttir, H. (2014). Second language acquisition: the effect of age, exposure and motivation. University of Iceland, Iceland. School of Humanities Department of English. https://pdfs.semanticscholar.org/9fd2/84e3122be3139177bc929927f06c2c1798d9.pdf?_ga $=2.130046991 .1659059289 .1585083761-490804295.1585083761$ adresinden 3 Temmuz 2019 tarihinde edinilmiştir.

Tok, H. ve Arıbaş, S. (2008). Avrupa birliğine uyum sürecinde yabanc1 dil öğretimi. İnönü Üniversitesi Eğitim Fakültesi Dergisi, 9 (15): 205-227. https://doi.org/10.19171/uuefd.29695

Tokdemir, A. (1997). Dil edinimi ve yabancı dil. (1. bask1). Ankara: Sam Yayınları.

Uygur, M. ve Çakır, Ö. (2015). İngilizce öğretmenliği lisans öğrencilerinin özyeterlik inançlarının farklı değişkenlere göre incelenmesi (Mersin üniversitesi örneği-boylamsal çalışma). Journal of Qafqaz University- Philology And Pedagogy, 3(1): 89-104. https://doi.org/10.24010/soid.490812

Wypusz, J. (2015). Konzept Deutsch als fremdsprache nach Englisch (dafne) - notwendigkeit oder wunschvorstellung? empirische untersuchung in grundschulen in großpolen, Glottodidactica XLII/1, 81-91, Adam Mickiewicz University Press Poznań, https://pressto.amu.edu.pl/index.php/gl/article/view/4159/4243 adresinden 25 Temmuz 2019'da edinilmiştir. https://doi.org/10.14746/gl.2015.42.1.6

Yıldırım, A. ve Şimşek, H. (2016). Sosyal bilimlerde nitel araştırma yöntemleri. Ankara: Seçkin Yayıncilik.

Y1lmaz, F. (2007). İngilizce' nin Türkiye'de ikinci yabancı dil olarak Almanca öğretimine etkileri, Yayımlanmamış Yüksek lisans tezi. İstanbul Üniversitesi, Sosyal Bilimler Enstitüsü, İstanbul. https://doi.org/10.12780/uusbd187

Zamani, R. ve Ahangari, S. (2016). Characteristics of an effective English language teacher (eelt) as perceived by learners of English. International Journal of Foreign Language Teaching and Research, 4 (14): 69-88. 